\title{
Prokaryotic expression, purification and antigenicity analysis of African swine fever virus pK205R protein
}

\author{
Xulong Wu ${ }^{1}$, Lu Xiao, ${ }^{1, *}$, Bin Peng ${ }^{1}$, Yin Wang ${ }^{1,2}$, Zexiao Yang ${ }^{1,2}$, \\ Xueping Yao, ${ }^{1,2}$, Ling Hu${ }^{1}$, Xingyu Lin ${ }^{1}$ \\ ${ }^{1}$ College of Veterinary Medicine, Sichuan Agricultural University, Chengdu, Sichuan, 611130, China \\ ${ }^{2}$ Key Laboratory of Animal Disease and Human Health of Sichuan Province, Chengdu, Sichuan, 611130, China
}

\begin{abstract}
African swine fever is an acute, febrile and highly virulent porcine disease causing serious economic losses worldwide. The pK205R protein of the African swine fever virus (ASFV) is largely expressed in the early stages of infection, which has given the $K 205 R$ gene extensive attention. In this study, the ASFV K205R was cloned and expressed in Escherichia coli BL21 (DE3). Expression of histidine-tagged $\mathrm{pK} 205 \mathrm{R}$ with a molecular mass of $44 \mathrm{kDa}$ was determined by $12 \%$ sodium dodecyl sulfate-polyacrylamide gel electrophoresis (SDS-PAGE) and Western blot analysis. Optimisation of culture conditions allowed induction of the recombinant protein with $0.4 \mathrm{mM}$ Isopropyl $\beta$-D-thiogalactoside (IPTG) at $37^{\circ} \mathrm{C}$ for $2 \mathrm{~h}$. The protein existed in cellular supernatant and was purified using a Ni-NTA resin column. The purified protein was used to immunize rabbits four times to enable the production of polyclonal antibodies, and the antiserum titre was detected by ELISA. The results showed that the purified pK205R can react with ASFV positive serum specifically by Western blotting. The pK205R had high antigenicity, which indicated that pK205R could be used as an antigen for detection of ASFV-specific antibodies in ELISA testing, and the recombinant protein could contribute to further research of the action and structure of pK205R.
\end{abstract}

Key words: indirect ELISA, pK205R, polyclonal antibody, Western blotting

\section{Introduction}

African swine fever (ASF) is an acute and highly virulent porcine disease, which results in high mortality in swine causing serious economic losses worldwide. The virus causes a haemorrhagic in domestic pigs, but persistently infects the natural hosts (warthogs and bushpigs) as well as soft ticks of the
Ornithodoros genus with no signs of disease (Burrage 2013, Oganesyan et al. 2013). The clinical symptoms of ASF are very similar to classical swine fever, and the two diseases normally have to be distinguished by laboratory diagnosis (Ronish et al. 2011). African swine fever virus (ASFV) can be detected in the swine's tonsils, mandibular lymph nodes and other organs, and will spread throughout the body with subse-

Correspondence to: Yin Wang, e-mail: yaanwangyin@tom.com, tel: +86132083598 88

* These authors contributed equally 
quent viremia (Gomez-Villamandos et al. 2013). To date, vaccines for ASF have not provided effective protection (Paton and Taylor 2011).

African swine fever virus is a double-stranded DNA virus which replicates in the cytoplasm of infected cells and is the only member of the Asfarviridae family (Sanchez et al. 2013, Takamatsu et al. 2013). Montgomery first described ASF in Kenya in 1921 (Montgomery 1921). The virus was next reported in Portugal, France, Belgium and other European countries in the 1980s (Wieland et al. 2011, Sampoli Benitez et al. 2013, Uttenthal et al. 2013). Currently, ASFV has crossed the Atlantic Ocean and outbreaks have been reported on some Caribbean islands, including Cuba and the Dominican Republic (de Glanville et al. 2014). The recent outbreak of ASFV outside of Africa was in Georgia at the beginning of 2007, and it has since spread to Azerbaijan and Russia (Diaz et al. 2012, Uttenthal et al. 2013). To date, there has been no recorded occurrence of ASF in China, but in the context of globalisation, with the development of import and export trade and frequent movement of personnel, ASF may soon extend to China.

So far, the biological function of ASFV pK205R is not completely clear, but immunofluorescence techniques showed that $\mathrm{pK} 205 \mathrm{R}$ is increasingly expressed in Vero cells (Gutierrez-Castaneda et al. 2008, Cubillos et al. 2013), and pK205R can be detected dispersing in the cytoplasm through fluorescent microscopy $4 \mathrm{~h}$ after artificial infection of Vero cells (Cubillos et al. 2013). Then $\mathrm{pK} 205 \mathrm{R}$ is gathered near the cell nucleus, which suggested that pK205R participates in the assembly of virions (Gutierrez-Castaneda et al. 2008). In addition, the pK205R protein antibody appears early in the infection, which contributes to early detection and treatment. In this study we described the construction of an expression plasmid, expressed it in Escherichia coli, and analysed the antigenicity after purification. Afterwards, ELISA and Western blot analysis demonstrated that the recombinant protein exhibited high antigenicity.

\section{Materials and Methods}

\section{Plasmids, bacterial strains and animals}

The $K 205 R$ whole gene sequence was synthesised by Invitrogen (Shanghai, China), with reference to NCBI (GenBank: NC_001659.1). Escherichia coli DH5h and BL-21 (DE3) were used as host strains and were saved at the Animal Quarantine Laboratory, Sichuan Agricultural University, China. The expression vector pET-32a was also preserved by the Animal Quarantine Laboratory. The pMD18-T Simple Vector was purchased from TaKaRa BIO Inc., Dalian, China. The experimental rabbits were housed and fed at the laboratory at Sichuan Agricultural University, China, and were euthanised before the end of the study with permission.

\section{Cloning the $K 205 R$ gene and construction of the expression plasmid}

A pair of primers were designed as shown below to amplify the $K 205 R$ gene; $B g l$ II and Not I restriction sites were incorporated in the sense primer and antisense primer, respectively. The sense primer P1 was 5'-AGATCTATGGTTGAGCCACGCGA-3' (Bgl II restriction sites), and the antisense primer $\mathrm{P} 2$ was 5'-GCGGCCGCCTTCTTCATCATCTCTT-3' (Not I restriction sites). Polymerase chain reaction was carried out as follows: initial denaturation at $94^{\circ} \mathrm{C}$ for 5 min, followed by 30 consecutive cycles of denaturing at $94^{\circ} \mathrm{C}$ for $45 \mathrm{~s}$, annealing at $60^{\circ} \mathrm{C}$ for $45 \mathrm{~s}$, synthesising at $72^{\circ} \mathrm{C}$ for $1 \mathrm{~min}$, and the final elongation at $72^{\circ} \mathrm{C}$ for $10 \mathrm{~min}$. The PCR product was purified using the TaKaRa MiniBEST Agarose Gel DNA Extraction Kit (TaKaRa BIO Inc., Dalian, China). The purified DNA was ligated into the pMD18-T Simple Vector using T4 DNA ligase (TaKaRa), and the ligated constructs were transformed into E. coli DH5a cells cultured under ampicillin $(100 \mu \mathrm{g} / \mathrm{ml})$. The recombinant plasmid pMD18T-K205R construction was confirmed by DNA sequencing (Life Technology Inc, Shanghai, China).

The recombinant plasmid pMD18-T-K205R and pET-32a were both digested with $\mathrm{Bgl}$ II and Not I (TaKaRa BIO). The digested products were ligated into expression vector pET-32a at $B g l$ II/ Not I sites, and the pET32a-K205R were transformed into $E$. coli BL21 (DE3). A positive colony was selected from an LB agar plate containing $100 \mu \mathrm{g} / \mathrm{ml}$ of ampicillin.

\section{Optimisation of expression conditions and identification of the protein expression form}

Logarithmic phase E. coli BL21 (DE3) were induced in different concentrations of Isopropyl $\beta$-D-thiogalactoside (IPTG, $0 \mathrm{mM}, 0.2 \mathrm{mM}, 0.4 \mathrm{mM}$, $0.6 \mathrm{mM}$ and $0.8 \mathrm{mM}$ ) and the samples were collected at different time-points $(0 \mathrm{~h}, 2 \mathrm{~h}, 4 \mathrm{~h}, 6 \mathrm{~h}$ and $8 \mathrm{~h})$ after the addition of IPTG. The centrifuged cells were mixed with loading buffer and heated for $5 \mathrm{~min}$ at $100^{\circ} \mathrm{C}$ after induction, and then analysed by $12 \%$ sodium dodecyl sulfate-polyacrylamide gel electrophoresis (SDS-PAGE). 
To identify the existing form of the protein (soluble protein or inclusion bodies), the induced products were harvested by centrifugation at $12,000 \mathrm{~g}$ for 10 min after ultrasonic disintegration on ice. The clear supernatant and the pellet were collected and analysed by SDS-PAGE followed by Coomassie Brilliant Blue (CBB, R-250) staining.

\section{Expression and purification of the protein}

The protein expression was induced with the optimal concentration of IPTG and time. Negative control cultures containing the empty pET-32a vector were processed in parallel. To obtain the recombinant protein, the host cells were collected from LB broth by centrifugation at $5000 \mathrm{rpm}$ for $20 \mathrm{~min}$, the cells were then re-suspended in deionised water, centrifuged at $10000 \mathrm{rpm}$ for $10 \mathrm{~min}$ after ultrasonic disintegration on ice, and the clear supernatant was collected. The recombinant protein was purified with Ni-nitrilotriacetate (NTA) resin (Qiagen, CA, USA), according to the manufacturer's procedure, and the eluted fractions were analysed by $12 \%$ SDS-PAGE.

\section{Production of polyclonal antibodies against the recombinant protein}

The purified protein was used for producing antibodies in Chinese domestic rabbits. Pre-immunised rabbit serum was used as a negative control. The rabbits were first immunised subcutaneously using $500 \mu \mathrm{g}$ recombinant protein in Freund's complete adjuvant. Three booster immunisations were performed with $500 \mu \mathrm{g}$ recombinant protein each in incomplete Freund's adjuvant at $1 \mathrm{wk}$ intervals, and the antiserum was collected after the last booster.

\section{Western blotting}

The $\mathrm{pK} 205 \mathrm{R}$ protein was tested by Western blotting. The purified recombinant protein was analysed on $12 \%$ SDS-PAGE and electro-transferred onto a nitrocellulose membrane. The membrane was blocked with $1 \%$ bovine serum albumin (BSA, Sigma, MO, USA) at $30^{\circ} \mathrm{C}$ for $2 \mathrm{~h}$, and then incubated with standard positive serum of ASFV from swine (ID.VET, Montpellier, France) at a dilution of 1:100 for $2 \mathrm{~h}$ at $30^{\circ} \mathrm{C}$. The membrane was washed three times by PBS-T (0.05\% Tween 20 in PBS), and then incubated in rabbit anti-swine HRP-IgG (Sigma) for $1 \mathrm{~h}$ at $30^{\circ} \mathrm{C}$. The empty pET-32a vector cultures were used as negative controls in parallel. The immunoreactive protein was visualised using the Western blot analysis system.

\section{Antiserum titre determination by ELISA}

Antibody titre was measured using indirect ELISA (Hu et al. 2015, Shenyang et al. 2007). The ELISA plates were coated with purified recombinant protein (1:160 dilution, approximately $6.5 \mu \mathrm{g} / \mathrm{ml}, 100$ $\mu \mathrm{l} /$ well $)$ at $37^{\circ} \mathrm{C}$ for $1 \mathrm{~h}$, then $4^{\circ} \mathrm{C}$ overnight, and washed three times with PBS-T $(0.05 \%$ Tween 20 in PBS). Each well of the unbound area was blocked with $1 \%$ BSA for $1 \mathrm{~h}$ at $37^{\circ} \mathrm{C}$ and washed as described above. Different dilutions $(1: 1,000$ to $1: 1,024,000)$ of $100 \mu \mathrm{l}$ polyclonal antibody against $\mathrm{pK} 205 \mathrm{R}$ were then added and the plates were incubated for $1 \mathrm{~h}$ at $37^{\circ} \mathrm{C}$. Pre-immunised rabbit serum was used as a negative control. The plates were washed four times and incubated with $100 \mu \mathrm{l}$ horseradish peroxidase-conjugated (HRP) goat anti-rabbit IgG (dilution 1:4000, Sigma) for $1 \mathrm{~h}$ at $37^{\circ} \mathrm{C}$. The o-phenylenediamine (OPD) substrate solution $(100 \mu \mathrm{l} /$ well $)$ was added after four rounds of washing, and the wells were incubated for $15 \mathrm{~min}$ at $37^{\circ} \mathrm{C}$ in the dark. Coloration was stopped with $1 \mathrm{M}$ of $\mathrm{H}_{2} \mathrm{SO}_{4}$ and the absorbance was measured at $450 \mathrm{~nm}$ using Microplate Reader (Bio-Rad, Model 680, USA).

\section{Results}

\section{Construction of the prokaryotic expression vector pET-32a-K205R}

The ASFV K205R gene was amplified and a 631 bp fragment was separated via $1.2 \%$ agarose gel electrophoresis (Fig. 1A). The purified K205R gene was cloned in E. coli cells (DH5 $\alpha$ ). Subsequently, the expression plasmid pET-32a-K205R was digested with the restriction enzymes $B g l$ II and Not I. Agarose gel electrophoresis results showed that two component fragments, at approximately $631 \mathrm{bp}$ and $5900 \mathrm{bp}$, were in good agreement with the predicted sizes (Fig. 1B). The constructed pET-32a-K205R was verified by DNA sequencing.

\section{Conditions optimal for protein expression}

Small-scale optimisation assays were carried out to identify the optimal culture conditions. Using different concentrations of IPTG $(0 \mathrm{mM}, 0.2 \mathrm{mM}$, $0.4 \mathrm{mM}, 0.6 \mathrm{mM}$ and $0.8 \mathrm{mM}$ ) the cells were induced at $37^{\circ} \mathrm{C}$ for $6 \mathrm{~h}$, and the expression capacity was 

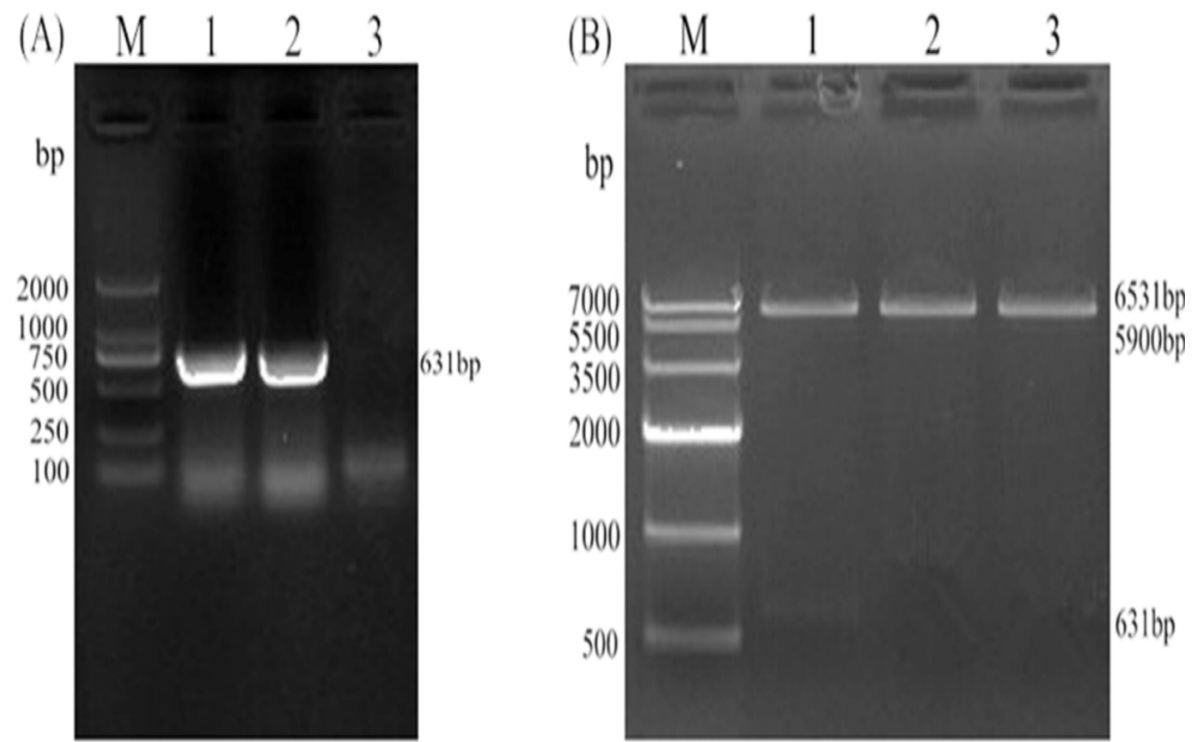

Fig. 1. Amplification of K205R gene and digestion of recombinant plasmid pET-32a-K205R construction. (A) Lanes 1-2: PCR products of ASFV K205R gene; lane 3: negative control; Lane M: DNA Marker. (B) Lane 1: Plasmid pET-32a-K205R was digested with $B g l$ II and Not I; lane 2: Plasmid pET-32a-K205R was digested with Bgl II; lane 3: Plasmid pET-32a-K205R was digested with Not I. Lane M: DNA Marker.

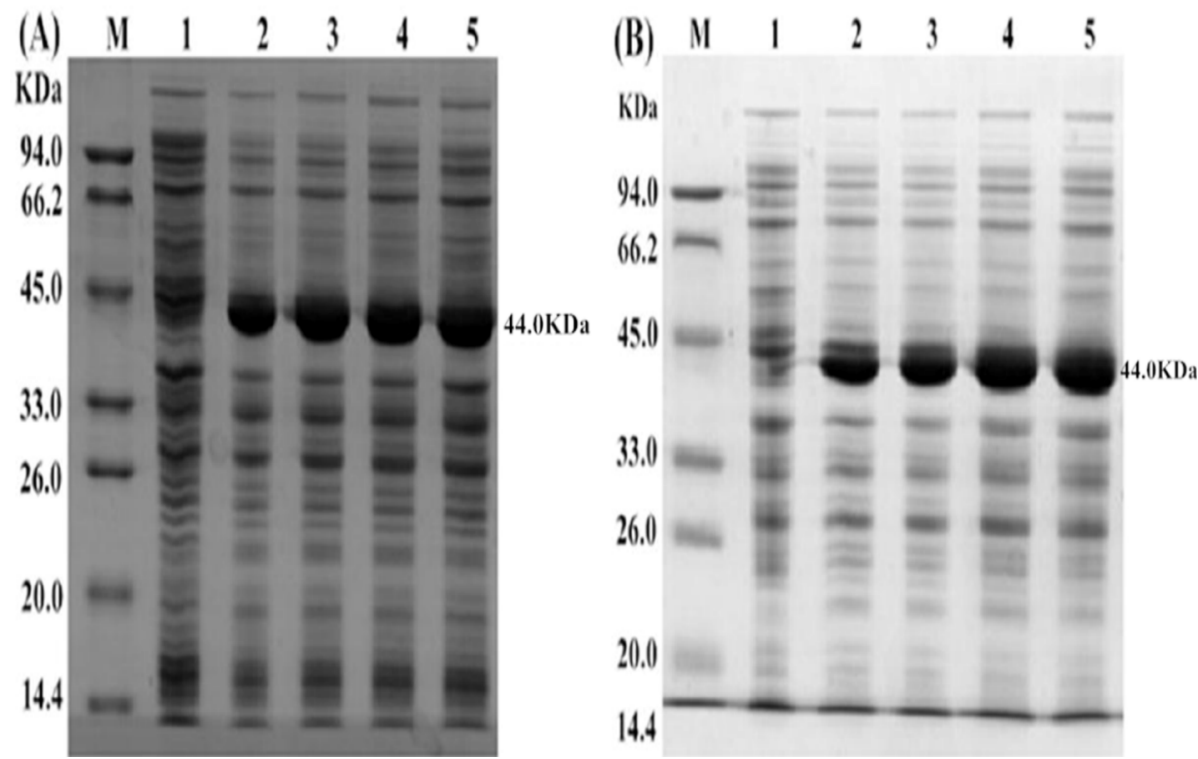

Fig. 2. Optimization of expression conditions. (A) Lanes 1-5: Concentration of IPTG was $0 \mathrm{mM}, 0.2 \mathrm{mM}, 0.4 \mathrm{mM}, 0.6 \mathrm{mM}, 0.8$ $\mathrm{mM}$, respectively. (B) Lanes 1-5: Cells were induced for 0 h, 2 h, 4 h, 6 h and 8 h by IPTG. Lane M: Protein Marker.

analysed by SDS-PAGE. Little difference was observed between the 0.4 to $0.8 \mathrm{mM}$ concentrations of IPTG and the negative control did not react (Fig. 2A). In addition, $0.4 \mathrm{mM}$ IPTG induced the cells at $37^{\circ} \mathrm{C}$ for different lengths of times $(0 \mathrm{~h}, 2 \mathrm{~h}, 4 \mathrm{~h}, 6 \mathrm{~h}$ and $8 \mathrm{~h}$ ). Analysis with SDS-PAGE showed the expression protein was sufficient after $2 \mathrm{~h}$ at $37^{\circ} \mathrm{C}$ (Fig. 2B).
Therefore, a $0.4 \mathrm{mM}$ concentration of IPTG and induction for $2 \mathrm{~h}$ were considered to be the optimal conditions for pET-32a-K205R expression. Furthermore, the cell supernatant and cell pellet were analysed after sonication, and the protein was found to be mainly distributed in the supernatant. 

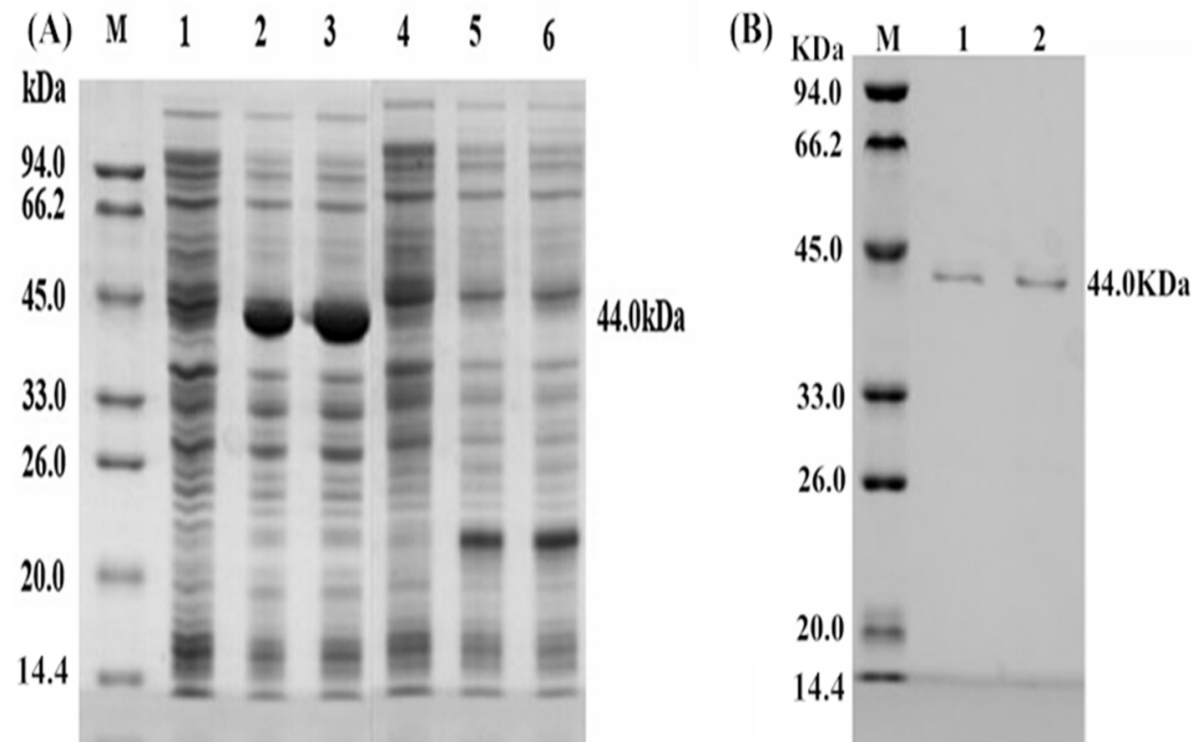

Fig. 3. Expression and purification of the fusion protein were analyzed by SDS-PAGE. (A) Lane 1: uninduced cells; lane 2: cells were induced for $2 \mathrm{~h}$; lane 3: cells were induced for $4 \mathrm{~h}$; lane 4: uninduced empty vector pET-32a; lanes 5-6: empty vector pET-32a was induced. (B) SDS-PAGE analysis of purified protein (lanes 1-2). Lane M: Protein Marker.

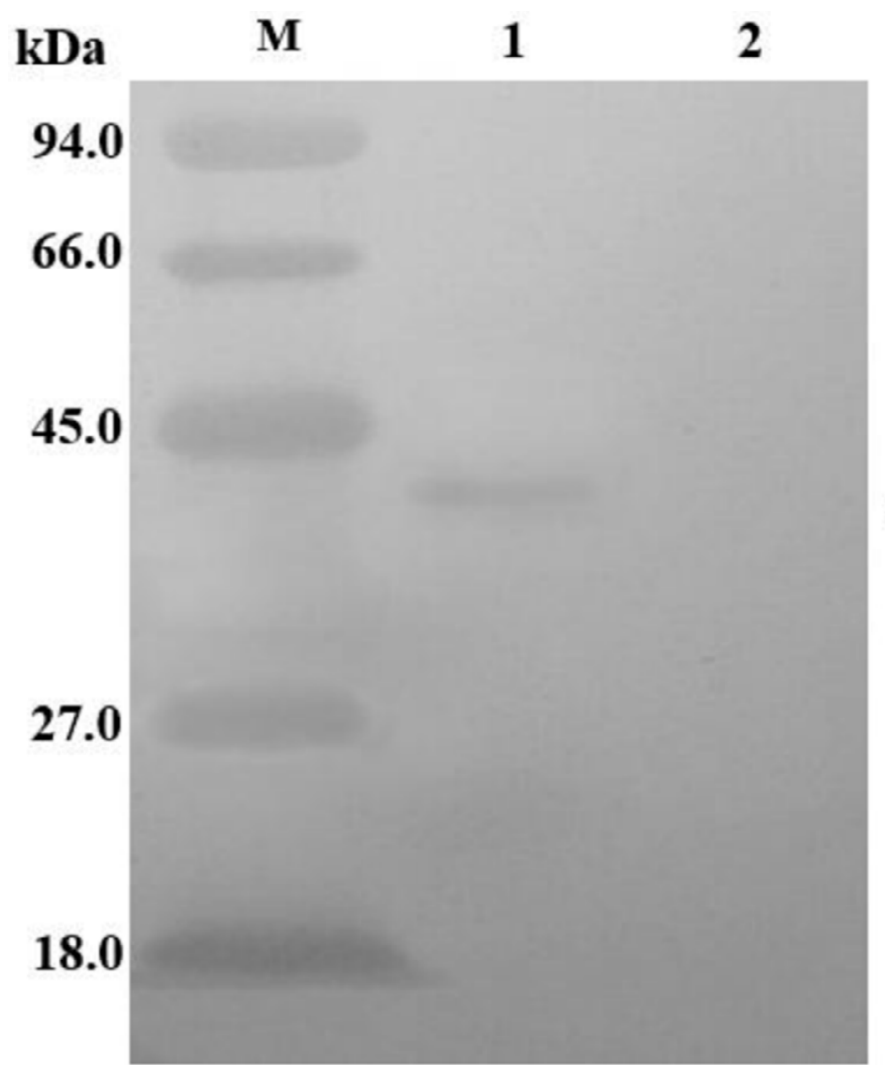

\section{0kDa}

Fig. 4. Western blotting. Lane M: Pre-stained protein molecular weight marker. Lanes 1-2: Expression of purified protein was incubated with positive and negative porcine serum against ASFV, respectively.

\section{Expression and purification of the pK205R protein}

The expression of recombinant protein was induced at $37^{\circ} \mathrm{C}$ for $2 \mathrm{~h}$ with $0.4 \mathrm{mM}$ IPTG. The protein was approximately $44 \mathrm{kDa}$ (Fig. 3A). The expression cells were sonicated on ice with an ultrasonic disintegrator (Ningbo XinYi Co, Ltd, China) until it turned clear. The supernatant was loaded onto a pre-equilibrated Ni-NTA affinity column followed by elution. The purified protein had an expected molecular mass of $44 \mathrm{kDa}$ (Fig. 3B). 

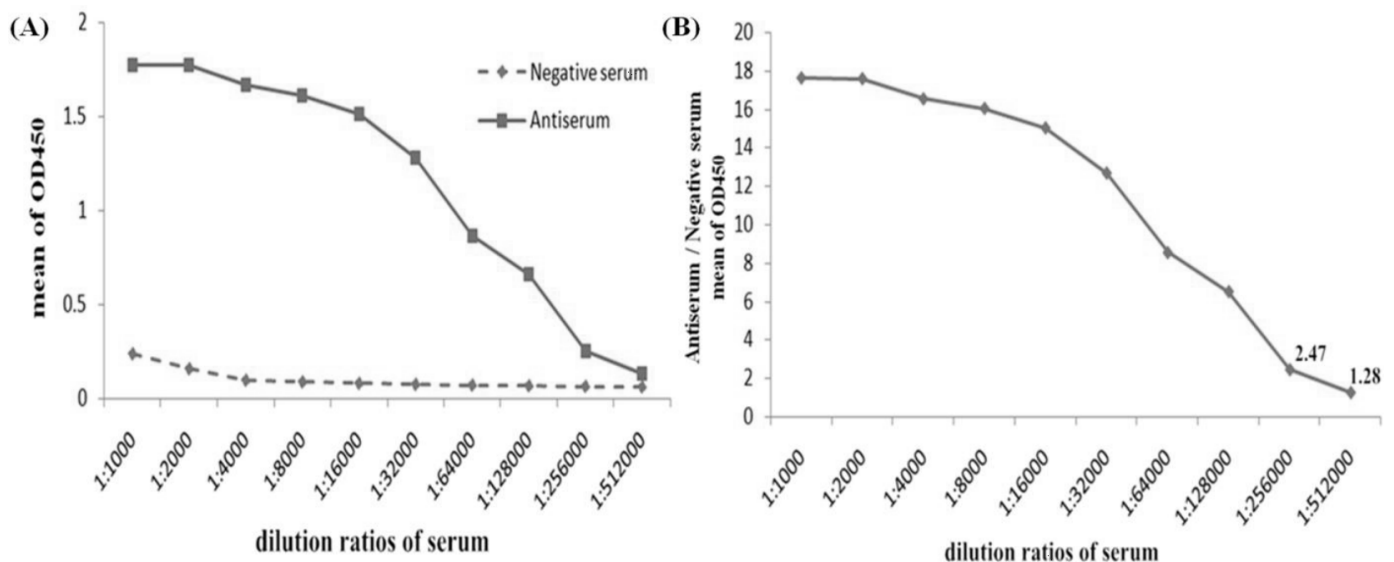

Fig. 5. Titer determination of polyclonal antibodies by ELISA. (A) Absorbance values at $450 \mathrm{~nm}$ of rabbit serum taken after the final immunization, and dilution at different ratios. (B) The ratio of anti-serum absorbance values at $450 \mathrm{~nm}$ compared with negative serum.

\section{Western blotting}

The purified protein was used as the antigen, ASF standard positive serum was used as the antibody and rabbit anti-swine HRP-IgG was used as the second antibody. Western blotting analysis showed that the recombinant protein band was $44.0 \mathrm{kDa}$ (Fig. 4). The result indicated that the $\mathrm{pK} 205 \mathrm{R}$ protein can react with ASF standard positive serum specifically.

\section{Antiserum titre determination by ELISA}

Rabbits were immunised with purified recombinant protein to generate the polyclonal antibody, and the final titre of antiserum was detected by ELISA. Prior to the first immunisation, blood samples were taken for the negative control. The mean $\mathrm{OD}_{450 \mathrm{~nm}}$ of the negative control was 0.1008 , and the mean $\mathrm{OD}_{450 \mathrm{~nm}}$ of the negative control plus double standard deviation (SD) was 0.2124. As shown in Figure 5, the dilution ratio of serum ranged from 1:1000 to $1: 512,000$. The absorbance value ratio of antiserum to negative serum was $2.47(1: 256,000)$ and 1.28 $(1: 512,000)$ (Fig. 5). Therefore, the antiserum titre was determined to be $1: 256,000$.

\section{Discussion}

African swine fever is a contagious viral disease which can cause up to $100 \%$ mortality among domestic pigs, leading to serious socio-economic consequences (Atuhaire et al. 2013). There are few studies on ASFV K205R. The K205R gene is a conserved and specific gene of ASFV that appears in early infection and it amplifies the fastest (Gutierrez-Castaneda et al. 2008); these features have made it a focus of ASFV research. In addition, pK205R can be expressed in early infection, which makes it a powerful and available indicator for rapid detection of ASFV.

We chose an E. coli BL21 expression system to express the pK205R protein. This is a rapid and economic assay and it can complete a fairly comprehensive analysis in a relatively short time. The BL21 strain is protease-deficient and designed for high-level protein expression from T7 RNA polymerase-based expression systems (Zhang et al. 2003). It has the advantage of being naturally lacking the Lon protease and is engineered to be deficient for the OmpT protease (Baneyx and Mujacic 2004, Pacheco et al. 2012). The Lon and OmpT proteases found in other E. coli expression hosts may interfere with the isolation of intact recombinant protein. In this study, we selected BL21 (DE3) as the host bacterial strain in which the recombinant protein was over-expressed.

Small-scale test expressions are widely used as a predictive tool to determine the suitable IPTG concentration and induction time for large-scale growth. The expression level tended to be constant when the IPTG concentration was $0.4 \mathrm{mM}$ and the induction time was over $2 \mathrm{~h}$ at $37^{\circ} \mathrm{C}$. The cells were inducted, and the clear supernatant and pellet were analysed by SDS-PAGE; the results showed that the soluble protein existed in the clear supernatant. The constructed recombinant plasmid pET-32a-K205R carrying 6-His-tagged protein was conducive to the purification of protein (Liu et al. 2011). The protein purification system is based on Ni-NTA resins for recombinant protein carrying a small affinity tag consisting of six consecutive histidine residues. The high affinity of the Ni-NTA resins for 6-His-tagged protein is due to both the specificity of the interaction between histidine residues and immobilised nickel ions and to the strength with which these ions are held to the NTA 
resin (Kirk 2014). Purified protein was used as the antigen to prepare the antiserum by immunising rabbits. The antiserum titre was detected by ELISA and Western blot analysis which showed that the pK205R protein had high antigenicity. This indicated that the pK205R protein could be used as an antigen for detection of ASFV-specific antibody in ELISA testing, and the recombinant protein could contribute to vaccine research of African swine fever.

\section{Conclusion}

In conclusion, $\mathrm{pK} 205 \mathrm{R}$ had a high level of expression in E. coli BL21 under optimal expression conditions, and purified protein was obtained based on Ni-NTA resin and plasmids carrying 6-His-tagged protein. Enzyme-linked immunosorbent assay and Western blot analysis indicated that the pK205R protein had high antigenicity. In summary, we obtained a highly purified protein which will enable further investigation into the mechanism of $\mathrm{pK} 205 \mathrm{R}$ action and structure. In addition, the recombinant protein could be used as an antigen to develop ELISA detection technology for ASFV. Although there has been no recorded occurrence of ASF in China, this method holds great potential for preventing ASFV spread into China.

\section{Acknowledgements}

We gratefully acknowledge financial support for this work from the planning subject of „the twelfth five-year-plan" in national science and technology for rural development in China (2013BAD12B04).

\section{References}

Atuhaire DK, Afayoa M, Ochwo S, Mwesigwa S, Mwiine FN, Okuni JB, Olaho-Mukani W, Ojok L (2013) Prevalence of African swine fever virus in apparently healthy domestic pigs in Uganda. BMC Vet Res 9: 263.

Baneyx F, Mujacic M (2004) Recombinant protein folding and misfolding in Escherichia coli. Nat Biotechnol 22: $1399-1408$.

Burrage TG (2013) African swine fever virus infection in Ornithodoros ticks. Virus Res 173: 131-139.

Cubillos C, Gomez-Sebastian S, Moreno N, Nunez MC, Mulumba-Mfumu LK, Quembo CJ, Heath L, Etter EM, Jori F, Escribano JM, Blanco E (2013) African swine fever virus serodiagnosis: a general review with a focus on the analyses of African serum samples. Virus Res 173: 159-167.

de Glanville WA, Vial L, Costard S, Wieland B, Pfeiffer DU (2014) Spatial multi-criteria decision analysis to predict suitability for African swine fever endemicity in Africa. BMC Vet Res 10: 9.

Diaz AV, Netherton CL, Dixon LK, Wilson AJ (2012) African swine fever virus strain Georgia 2007/1 in Ornithodoros erraticus ticks. Emerg Infect Dis 18: 1026-1028.

Gomez-Villamandos JC, Bautista MJ, Sanchez-Cordon PJ, Carrasco L (2013) Pathology of African swine fever: the role of monocyte-macrophage. Virus Res 173: 140-149.

Gutierrez-Castaneda B, Reis AL, Corteyn A, Parkhouse RM, Kollnberger S (2008) Expression, cellular localization and antibody responses of the African swine fever virus genes B602L and K205R. Arch Virol 153: 2303-2306.

Hu Z, Chen Z, Huang N, Teng X, Zhang J, Wang Z, Wei X, Qin K, Liu X, Wu X, Tang H, Zhu X, Cui K, Li J (2015) Expression, purification of IL-38 in Escherichia coli and production of polyclonal antibodies. Protein Expr Purif 107: 76-82.

Kirk WR (2014) Thermodynamics of imidazole-ligand binding to Ni-nitrilotriacetate in solution and covalently attached to agarose beads: imidazole, his-6 (his-tag) peptide and a new bis-imidazolo-dithiane. Protein Expr Purif 95: 1-7.

Liu D, Si B, Li C, Mi Z, An X, Qin C, Liu W, Tong Y (2011) Prokaryotic expression and purification of HA1 and HA2 polypeptides for serological analysis of the 2009 pandemic H1N1 influenza virus. J Virol Methods 172: 16-21.

Montgomery RE (1921) On a form of swine fever occurring in British East Africa (Kenya Colony). Journal of Comparative Pathology 34: 159-191.

Oganesyan AS, Petrova ON, Korennoy FI, Bardina NS, Gogin AE, Dudnikov SA (2013) African swine fever in the Russian Federation: spatio-temporal analysis and epidemiological overview. Virus Res 173: 204-211.

Pacheco B, Crombet L, Loppnau P, Cossar D (2012) A screening strategy for heterologous protein expression in Escherichia coli with the highest return of investment. Protein Expr Purif 81: 33-41.

Paton DJ, Taylor G (2011) Developing vaccines against foot-and-mouth disease and some other exotic viral diseases of livestock. Philos Trans R Soc Lond B Biol Sci 366: 2774-2781.

Ronish B, Hakhverdyan M, Stahl K, Gallardo C, Fernandez-Pinero J, Belak S, Leblanc N, Wangh L (2011) Design and verification of a highly reliable Linear-After-The-Exponential PCR (LATE-PCR) assay for the detection of African swine fever virus. J Virol Methods 172: 8-15.

Sampoli Benitez B, Barbati ZR, Arora K, Bogdanovic J, Schlick T (2013) How DNA polymerase X preferentially accommodates incoming dATP opposite 8-oxoguanine on the template. Biophys J 105: 2559-2568.

Sanchez EG, Quintas A, Nogal M, Castello A, Revilla Y (2013) African swine fever virus controls the host transcription and cellular machinery of protein synthesis. Virus Res 173: 58-75.

Shenyang G, Enhui Z, Baoxian L, Xinyuan Q, Lijie T, Junwei G, Yijing L (2007) High-level prokaryotic expression of envelope exterior of membrane protein of porcine epidemic diarrhea virus. Vet Microbiol 123: 187-193.

Takamatsu HH, Denyer MS, Lacasta A, Stirling CM, Argilaguet JM, Netherton CL, Oura CA, Martins C, Rodriguez $\mathrm{F}$ (2013) Cellular immunity in ASFV responses. Virus Res 173: 110-121. 
Uttenthal A, Braae UC, Ngowi HA, Rasmussen TB, Nielsen J, Johansen MV (2013) ASFV in Tanzania: asymptomatic pigs harbor virus of molecular similarity to Georgia 2007. Vet Microbiol 165: 173-176.

Wieland B, Dhollander S, Salman M, Koenen F (2011)

Qualitative risk assessment in a data-scarce environment: a model to assess the impact of control measures on spread of African Swine Fever. Prev Vet Med 99: 4-14.

Zhang Y, Taiming L, Liu J (2003) Low temperature and glucose enhanced T7 RNA polymerase-based plasmid stability for increasing expression of glucagon-like peptide-2 in Escherichia coli. Protein Expr Purif 29: 132-139. 